\title{
THE EFFECT OF SBI RATE THROUGH FINANCIAL SYSTEM TO ECONOMIC GROWTH OF INDONESIA
}

\author{
Donni Fajar Anugrah'
}

\begin{abstract}
A bstraksi
Bank Indonesia menerapkan Inflation Targeting Framework (ITF) sejak tahun 2000 dengan menggunakan base money sebagai alat kebijakan moneternya. Hasil penerapan framework ini kurang optimal jika melihat inflasi aktual yang tidak selalu berada dalam kisaran target yang telah diumumkan. Di sisi lain, beberapa negara yang juga menerapkan ITF, seperti New Zealand, telah berhasil mencapai tingkat inflasi yang rendah sesuai dengan target yang diumumkan. Mereka menggunakan suku bunga sebagai alat kebijakan moneter dalam penerapan ITF. Oleh karena itu, Bank Indonesia memutuskan untuk menggunakan suku bunga SBI sebagai alat kebijakan untuk mencapai inflasi yang rendah.

Permasalahan yang perlu mendapat perhatian yaitu seberapa besar efek dari kebijakan ini terhadap pertumbuhan ekonomi secara bertahap. Dalam penerapannya, suku bunga SBI akan mempengaruhi sistem keuangan melalui suku bunga pasar, seperti suku bunga PUAB dan kredit. Secara teoritis kedua suku bunga pasar tersebut dapat mempengaruhi konsumsi dan investasi. Penelitian ini akan lebih difokuskan pada efek suku bunga pada konsumsi dan investasi yang pada akhirnya berdampak pada tingkat pertumbuhan ekonomi.

Dengan menggunakan pendekatan Johansen, akan dapat dijelaskan hubungan jangka panjang antar variabel dan menghasilkan ECM yang digunakan dalam model jangka pendeknya. Hasil penelitian menunjukkan bahwa suku bunga dan konsumsi memiliki hubungan negatif hanya di jangka pendek. Sedangkan suku bunga dengan investasi berhubungan negatif dalam jangka panjang. Hasil akhir menunjukkan peningkatan suku bunga akan berakibat pada penurunan pertumbuhan ekonomi.
\end{abstract}

Keywords: Central Bank, SBI rate, consumption, investment, economic growth, inflation targeting JEL Classification: E21, E52, E58, F43

1 The author is an economist at the Directorate of Economic Research and Monetary Policy, Bank Indonesia. Email: donni@bi.go.id 


\section{INTRODUCTION}

\section{I.1 Background}

Recently, some central banks have applied inflation targeting framework as part of their monetary policy, after the Reserve Bank of New Zealand introduced inflation targeting in early 1990s. However, it is not been proved whether inflation rate would be under control if the policy is in place. Bank Indonesia as a central bank of Indonesia is one of a number of countries in Asia applying inflation targeting. See Table IV.1.

\begin{tabular}{|c|c|c|c|}
\hline \multicolumn{3}{c}{ Table IV.1 } \\
\hline \multicolumn{1}{|c|}{ Inflation Targeting Framework in Asia } \\
\hline Country & Introduction & $\begin{array}{c}\text { Mid-term } \\
\text { Inflation Target }\end{array}$ & $\begin{array}{c}\text { Central Banking } \\
\text { Law Reform }\end{array}$ \\
Korea & Sep 1998 & $2.5 \%$ & Dec 1998 \\
Indonesia & Jan 2000 & $3-5 \%$ & May 1999 \\
Thailand & May 2000 & $0-3.5 \%$ & Under Discussion \\
Philipines & Jan 2001 (planned) & - & 1993 \\
\hline
\end{tabular}

Previously Bank Indonesia was targeting the monetary base as a temporary framework to absorb the monetary expansion. This is not the case for some other countries, such as New Zealand, Australia, United Kingdom, or South Korea, which were use interest rate rather than the money base (Iljas, 1999). Say New Zealand, which uses inflation targeting framework, uses inflation as base target and interest rate as instrument to reach its target.

\begin{tabular}{l|c|c}
\multicolumn{2}{c}{$\begin{array}{c}\text { Table IV.2 } \\
\text { Target of Inflation and Actual Inflation }\end{array}$} \\
\hline Year & $\begin{array}{c}\text { Inflation Target } \\
\text { (percentage, year on year) }\end{array}$ & $\begin{array}{c}\text { Actual Inflation } \\
\text { (percentage, year on year) }\end{array}$ \\
2000 & $3-5 \%$ & 9.35 \\
2001 & $6-8.5 \%$ & 12.55 \\
2002 & $9-10 \%$ & 10.03 \\
& (in 5 years target 6-7 \%) & \\
\hline 2003 & $9 \%$ deviation 1\% & 5.06 \\
2004 & $5.5 \%$ deviation 1\% \\
2005 & $6 \%$ deviation 1\% & 6.40 \\
\hline
\end{tabular}


Regarding to the preliminary implementation of inflation targeting framework (ITF), Bank Indonesia should clearly use single nominal anchor which is supported by an accurate economic model and data. Inflation targeting and base money targeting is not exclusive alternative, but it is possible applying the monetary base as the instrument to reaching target $^{2}$. Even though it is possible for Bank Indonesia still applying money growth as instrument policy, Bank Indonesia may adopt an inflation targeting based on interest rate. (Need to be clarified)

Bank Indonesia has applied interest rate base in 2005 by using the SBI (Certificate of Bank Indonesia) rate as an instrument policy. The SBI rate or central bank's rate has showed the different pattern with the GDP growth. Increasing SBI rate is followed by decreasing GDP growth. By monetary transmission mechanism, interest rate has possibility to affect economic growth indirectly ${ }^{3}$.

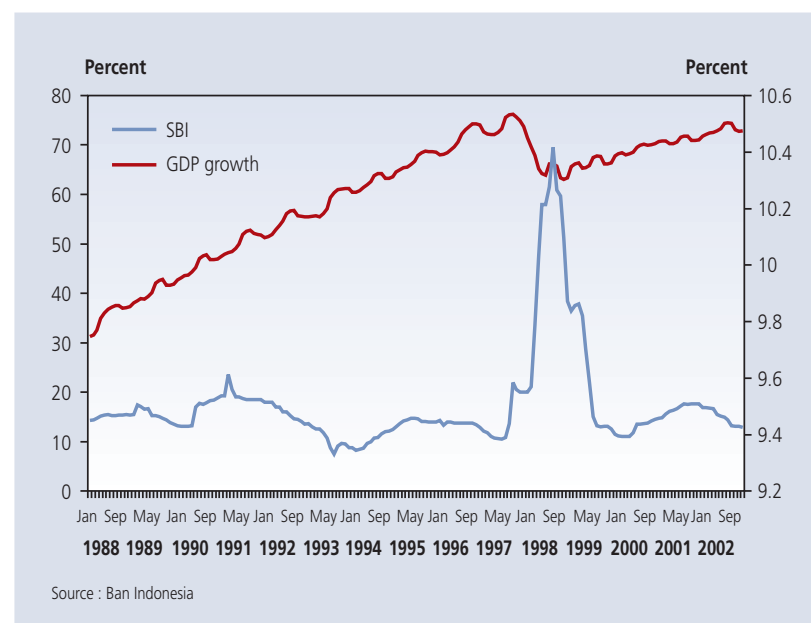

Figure IV.1. SBI Rate and GDP Growth

However, Bank Indonesia needs to investigate the effect of the SBI rate through financial system to GDP growth gradually. Firstly, how much the effect of SBI rate to interest rate in financial system, then how much the effect of real interest rate to real consumption and real investment, and finally to the economic growth.

\footnotetext{
2 Taylor, John B., "Summary Remarks at Bank Indonesia", prepared for the inflation targeting conference at Bank Indonesia, Jakarta, 2000

3 Warjiyo, Perry. and Agung, Juda., "Transmission Mechanism of Monetary Policy in Indonesia", Bank Indonesia, 2002
} 


\section{I.2 The Main Issue}

Bank Indonesia applies money growth as instrument policy to achieve price stability in inflation targeting framework. However, the result is not really optimal, since target inflation is sometimes missed. Meanwhile, some countries which applied inflation targeting framework has used interest rate as their instrument policy and they can reach the low and stable rate of inflation, such as New Zealand, United Kingdom, Australia, and so forth.

According to experience of New Zealand, Bank Indonesia considers to change its instrument policy from money growth to interest rate. The main problem is that it does not really know whether changes the instrument policy is better decision in Indonesia case. The changes instrument policy may have effect to the other macro economy variables and may cause the potential problems to Indonesia. These are the problem concern why we need to investigate on it. Therefore, it will become important issue that attracts attention not only by Bank Indonesia itself but also by among government, real sectors, and people.

\section{I.3 Objective of Research}

The research will start to overview the effect of SBI rate to interest rate in the financial market. It will investigate the link between SBI rate and market interest rate, also the link between SBI rate and lending rate. Furthermore, it will investigate the link of market interest rate and consumption, also the relation between lending rate and investment by constructing long run and short run model. The model should give a strong explanation the effect of interest rate to real sector (consumption and investment).

Finally, the research will show how far the effect of consumption and investment to the economic growth by developing simple regression model. Then, it summarizes the effect of SBI rate trough financial market to the real sector. Hopefully, it can give recommendation to Bank Indonesia according to applying interest rate as instrument policy in inflation targeting framework.

\section{I.4 Area of Research}

The research will concern itself with analyzing the effect of SBI rate (the nominal rate) on the real sectors of the economy, with specific attention on consumption and investment in Indonesia. Understanding of these factors can support the empirical studies, since they can support explaining the model economy. However, it focuses only on the effect of interest rate to consumption and investment when it constructs the long run and short run model. We 
apply market rate and lending rate as interest rate, because it can be indirectly determined by Bank Indonesia and can drive the market rate.

The sample period is fifteen years (1988-2002) to catch up the long run effect of interest rate to both consumption and investment. This period covers exchange rate crises period 19971999. Even though the role of exchange rate to influence interest in Indonesia cannot be ignored, it will not be investigated specifically on the relationship between exchange rate and interest rate. However, it will be applied in the short run model of investment.

\section{LITERATURE REVIEW}

\section{II.1 Interest Rate}

Certificate of Bank Indonesia called SBI (Sertifikat Bank Indonesia) is the one of instrument policies of Bank Indonesia as central bank of Indonesia. The SBI rate as central bank's rate guides the interest rate in the financial market, such as commercial bank's rate and lending rate. Therefore, rising SBI rate will influence financial market by increasing the commercial bank's rate and lending rate.

Many improvements are has to do for completing the monetary policy, especially the instrument to achieve the target. Like the other countries adopted inflation targeting framework with interest rate instrument to reach the target, Bank Indonesia can use the same method to achieve the target. Base money target should be left after implementing interest rate base (Warjiyo, 2001)

Taylor's rule developed by John Taylor ${ }^{4}$ suggests central bank a monetary policy rule such as how to set short term interest rate to achieve stabilizing economy in the short term and low level of inflation in the short run. The formula is:

$$
i_{t}=\pi_{t}+r^{*}+0.5\left(\pi_{t}-\pi^{*}\right)+0.5\left(y_{t}\right)
$$

Notes: central bank rate is denoted by $i_{t}$, equilibrium real central bank rate is denoted by $r^{*}$, inflation rate is denoted by $\pi_{t^{\prime}}$ target inflation rate is denoted by $\pi_{t}^{*}$, output gap is denoted by $y_{t}$

The commercial bank's rate can be defined as nominal interest rate in this paper. The difference between nominal interest rate and the expected inflation can be defined as the real interest rate. There is popular as Fisher equation ${ }^{5}$ :

\footnotetext{
4 Taylor, John B., "Discretion Versus Policy Rules in Practice," Carnegie-Rochester Conference Series on Public Policy, 39, 1993, p. 195214

5 Romer, David, Advanced Macroeconomic, Second Edition, McGraw-Hill, 2001, p.472.
} 
$i \equiv r+\pi^{e}$

Notes: $i$ is nominal interest rate, $r$ is real interest rate, and $\pi^{e}$ is expected inflation.

This equation means increasing the expected inflation by $1 \%$ in turn causes increasing the nominal interest rate by $1 \%$. The one for one relationship between the inflation rate and the nominal interest is called the Fisher effect (Mankiw, 2003).

The lending rate is the nominal interest rate that given by commercial bank to borrower who lend the fund from the banks. The real lending rate that is the nominal lending rate minus inflation rate can influence the real investment. Theory states that increasing the real lending rate can decrease the investment (Mankiw, 2003). Investors will increase their investment when the real lending rate is low. On the contrary, they will decrease their investment if the real lending rate is high. They want to get profit as much as they can get, therefore they will choose investing their money when the real lending rate is low.

\section{II.2 Economic Growth}

The best measure of economic performance of the country is Gross Domestic Product $(G D P)^{6}$. Central Bureau of Statistic (BPS) of Indonesia computes GDP every three months and divides GDP by expenditure and sectors. GDP by expenditure can be categorized by consumption, investment, government purchase, export and import. The formula is known as (Mankiw, 2003).

$Y=C+I+G+X-M$

Notes: GDP is denoted by $\mathrm{Y}$, consumption is denoted by $\mathrm{C}$, investment is denoted by $\mathrm{I}$, government purchase is denoted by $\mathrm{G}$, export is denoted by $\mathrm{X}$, and import is denoted by $\mathrm{M}$.

Consumption can be divided into three sub categories, such as non durable goods, durable goods, and services. The goods that can be used for only short time period are non durable goods, otherwise for the long time it is durable goods. Services are the work that given by professionals such as lawyer, consultants, and so forth (Mankiw, 2003).

The famous economist, Keynes, stated that the real disposable income is the most important factor to determine real consumption in the short run. This theory is called the Keynesian consumption function in which the formula:

$$
C=a+c^{*} Y_{d}
$$

Notes: real consumption is denoted by $C$, marginal propensity to consume (MPC) is denoted by 
$c$, MPC means the change in consumption divided by the change in income, and disposable income is denoted by $Y_{d^{\prime}}$ where is:

$$
Y_{d}=Y-T
$$

Notes: gross income is denoted by $Y$, and tax (direct and indirect tax) is denoted by $T$.

Moreover, consumption can be influenced by wealth and disposable income. Macklem? stated that wealth significantly influence consumption in the long run, but disposable income strongly determinant consumption in both the short run and long run. This influence may be explained as evidence of liquidity constraint.

Dreger and Reimers ${ }^{8}$ quoted from Campbell and Mankiw (1991) stated that according to the life-cycle permanent income hypothesis for consumption, consumption and disposable income are cointegrated in the long run in which the cointegration vector is $(1,-1)$. The permanent income hypothesis can be written:

$$
S_{t}=-\sum_{i=0}\left(\frac{1}{1+r}\right)^{i} E_{t} \Delta Y_{t+i}
$$

Notes: Saving is denoted by $S_{t^{\prime}}$ rational expectation operator is denoted by $E_{t^{\prime}}$ the first difference of labor income is denoted by $\Delta Y_{t+i}$. Savings will increase if labor income increase. If labor income is stationary, saving will stationary, therefore, disposable income and consumption are cointegrated. This paper will apply this hypothesis to obtain the long run relationship between consumption and disposable income.

The investment function relates the quantity of investment and the real lending rate. Meaning that the real investment depends on the real lending rate in which the real lending rate is the lending rate corrected by inflation, since it is the cost of borrowing (Mankiw, 2003). When the real lending rate is decreasing, the real investment will go up. On the other hand, investment will fall when the real interest rate goes up.

\section{II.3 The Long Run and The Short Run Model}

The economic model can be developed in the long run and short run structure to capture the link between variable in the long run and in the short run. The technique to get the ECM (error correction mechanism) in the long run equation is Johansen's technique and Engle-

\footnotetext{
7 Macklem, R. Tiff, "Wealth, Disposable Income and Consumption: Some Evidence for Canada", November 1994, p.4

8 Dreger, C. and Reimer, H.E., "Consumption and Income in the Euro Area: Empirical Evidence Based on Panel Cointegration Methods", 2000, p. $2-5$
} 
Granger's method. The Johansen's technique is more powerful than Engle Granger's method (Enders, 2004)

Most macroeconomic time series data are non stationary, therefore they have a crucial implication when developing econometric modeling. The data is divided in stationary and non stationary in which provided the framework for analysis in the long run relationship between variables in economics concepts ${ }^{9}$.

Starting with a vector auto regressive (VAR) model, Johansen formulates the hypothesis of cointegration as the hypothesis of reduced rank of the long run impact matrix $\pi=\alpha \beta^{\prime}$ and he defines both $\alpha$ (Alpha) and $\beta$ (Beta) to test other restrictions on the cointegrating vector ${ }^{10}$. The technique will be simple when the cointegration vector is one, otherwise it will be complicated. Suppose the $\pi$ or the rank is one meaning that the rows of $\pi$ are all linear multiples of each other (Enders, 2004). The form of equation:

$$
\begin{aligned}
& \Delta x_{1 t}=\pi_{11} x_{1 t-1}+\ldots+\pi_{1 n} x_{n t-1}+\ldots+\varepsilon_{1 t} \\
& \Delta x_{2 t}=S_{2}\left(\pi_{11} x_{1 t-I}+\ldots+\pi_{1 n} x_{n t-I}\right)+\ldots+\varepsilon_{2 t} \\
& \ldots \\
& \Delta x_{n t}=S_{n}\left(\pi_{11} x_{1 t-I}+\ldots+\pi_{1 n} x_{n t-I}\right)+\ldots+\varepsilon_{n t}
\end{aligned}
$$

Notes: the scalars is denoted by $s_{i}$. Defining $\alpha_{i}=s_{i} \pi_{1 j}$ and $\beta_{i}=\pi_{1 i} / \pi_{11}$, therefore the each equation in matrix form:

$$
\Delta x_{t}=\sum_{i=1}^{p-1} \pi_{i} \Delta x_{t-i}+\alpha \beta^{\prime} x_{t-i}+\varepsilon_{t}
$$

Notes: The single cointegrating vector is $\beta=\left(1, \beta_{2^{\prime}}, \ldots, \beta_{n}\right)^{\prime}$ and the speed of adjustment parameter is denoted by $\alpha=\left(\alpha_{1}, \alpha_{2}, \ldots, \alpha_{n}\right)^{\prime}$

After determining both $\alpha$ and $\beta$, the test statistic compares the number of cointegration vectors under the null and alternative hypotheses. Testing restrictions on $\beta$ applying the test statistic:

$$
T \sum_{i=1}^{r}\left[\ln \left(1-\lambda_{i}^{*}\right)-\left(1-\lambda_{i}\right)\right]
$$

9 Johansen, S. and Katarina, J., "Identification of The Long-Run and The Short-Run Structure an Application to The ISLM Model", Journal of Econometrics 63, 1994, p.8.

10 Johansen, S. and Katarina, J., "Maximum Likelihood Estimation and Inference on Cointegration - with Aplications to The Demand for Money", Oxford Bulletin of Economics and Statistics, 52, 1990, p.169-181 
The distribution in this case is $\chi^{2}$ distribution in which have degrees of freedom equal to number of $\beta$ restriction. Moreover, the $\alpha$ restriction can be tested in the similar way (Enders, 2004).

To determine the value of, $\lambda_{\text {trace }}$ and $\lambda_{\max }$ statistic is usually applied ${ }^{11}$. The formula is:

$$
\begin{aligned}
& \lambda_{\text {trace }}(r)=-T \sum_{i=r+1}^{n} \ln \left(1-\hat{\lambda}_{i}\right) \\
& \lambda_{\text {max }}(r, r+1)=-T \ln \left(1-\hat{\lambda}_{i}\right)
\end{aligned}
$$

Notes: $\hat{\lambda}_{i}$ is the eigenvalues (the estimated values of the characteristic roots obtained from the estimated $\pi$ matrix, and $T$ is the number of observations.

Error Correction Mechanism (ECM) is derived from long run equation. Calculation of ECM is dependent variable minus all explanatory variables, including intercept or trend. Function of ECM is to bring the equation to the equilibrium in the long run. Therefore the coefficient of ECM should be negative (Patterson, 2000).

\section{METHODOLOGY}

\section{III.1 Data}

We use published data provided by Bank Indonesia, Central Bureau of Statistic (BPS) of Indonesia, and CEIC with sample period 1988/1 - 2002/12. Those are real consumption, real investment, real GDP, real disposable income, SBI 1 month rate as a central bank rate, bank overnight rate as commercial bank rate, lending rate, real exchange rate and inflation rate. Disposable income is nominal GDP minus tax (oil tax, direct and indirect tax, non tax revenues government) divided by CPI (consumer price index) as price.

The real data of GDP, consumption, investment and disposable income are converted from quarterly data to monthly data by interpolation method that is quadratic-match sum. The method fits a local quadratic polynomial for each data of the low frequency series and uses this polynomial to fill in all data of the high frequency series associated with the period. For all points, one point before and after the period that currently observed is interpolated by providing three points. Furthermore, at the end points, the two periods are taken from the one side where observation is available ${ }^{12}$.

\footnotetext{
11 Enders, Walter, Applied Econometric Time Series, Wiley, 2004, p. 355-366

12 Eviews 4.1 provides explanation about quadratic-match sum method in the software help index.
} 


\section{III.2 Methodology}

We develop two simple models for interest rate and output each. They are developed by simple regression using OLS. The first model of interest rate is showing the effect of SBI rate to commercial bank's rate and the second model is indicating the effect of SBI rate to lending rate. Meanwhile, the first model of output is to measure the effect of consumption to output and the second model to show the effect of investment to output. Then, we do Granger causality test to find the causality between variables in each model.

This paper will focus on developing the long run models for consumption and investment by Johansen's technique, since it has more powerful than Engle Granger's method (Enders, 2004). The first step, we do stationary test of the data, since macroeconomic time series data is usually non stationary at the level and stationer at the first difference. Therefore, we will do unit root test for random walk variables, to find both the stationary of each variable and the order of integration for each variable. If all data are stationer at first difference I (1), the order of integration is one, meaning that all variable can be cointegrated in the long run (Patterson, 2000).

Cointegrating the variables by Johansen's technique is to obtain Eigenvalues. Meanwhile, doing both Trace statistic and Eigenvalues maximum test is to undertake the test for number of Eigenvalues that are insignificantly different from 1 (Johansen and Katarina, 1994). Furthermore, we do weakly exogeneity test to find whether the variable responds to the discrepancy from the long run relationship in cointegrated system. Therefore, the speed of adjustment parameter $\alpha_{1}$ should be zero to meet that the variable is weakly exogenous. The weakly exogenous variable does not experience the type of feedback that necessitates the use of VAR ${ }^{13}$.

The third step, we calculate the ECM from the long run equation of each model and put it in the short run equation. Then, we derive a parsimonious equation of consumption and investment. The coefficient of ECM should be negative to bring the equation to the equilibrium in the long run (Patterson, 2000).

The final step, we investigate whether the models have a structural change. When developing model by time series data, it is possible that the structural break is happened. Sometimes, the structural change may be caused by external forces or policy changes. To find the structural break, we can test the model by the Chow test. The Chow test needs the knowledge of the specific time of structural break allowing the sample to be split (Enders, 2004). Therefore, we apply recursive procedure in PC GIVE software to investigate the stability of the model estimates.

13 Enders, Walter, "Applied Econometric Time Series", 2004 


\section{EMPIRICAL RESULT AND ANALYSIS}

In this chapter, we do analysis of the empirical result. The statistic result is summarized on tables. The analysis is started with the simple regression model of interest rate and Granger causality between interest rate variables and is ended with the simple regression model of output and Granger causality between output and both consumption and investment. The main models are both consumption model and investment model that is developed in the long run and short run equations by Johansen's technique.

\section{IV.1 The Effect of SBI Rate to Interest Rate at Financial System}

The model of interest rate will reveal how much effect of SBI rate to both the commercial bank's rate as nominal interest rate and lending rate in the financial market. By plotting the data of SBI rate, commercial bank's rate, and lending rate, the graph provides the positive relationship among them. The rising SBI rate is followed by increasing both commercial bank's rate and lending rate (Figure IV.2, IV.3 and IV.4).

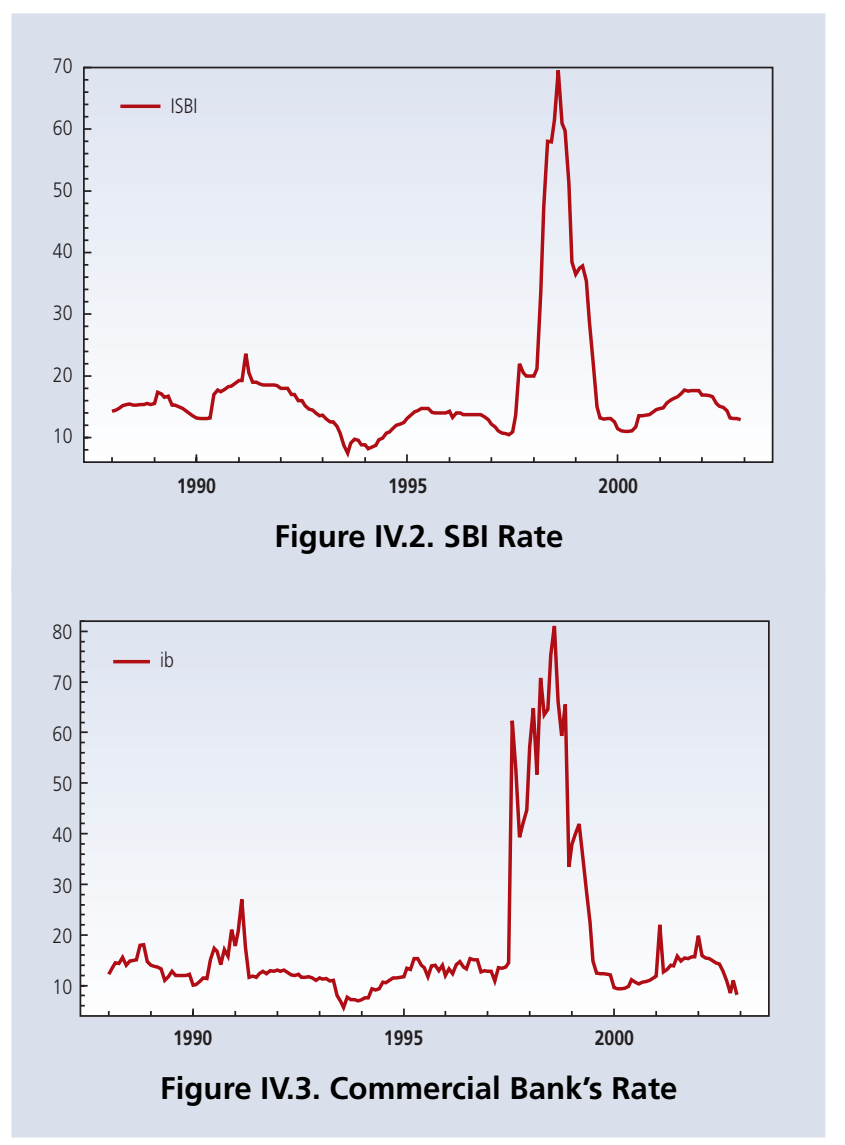




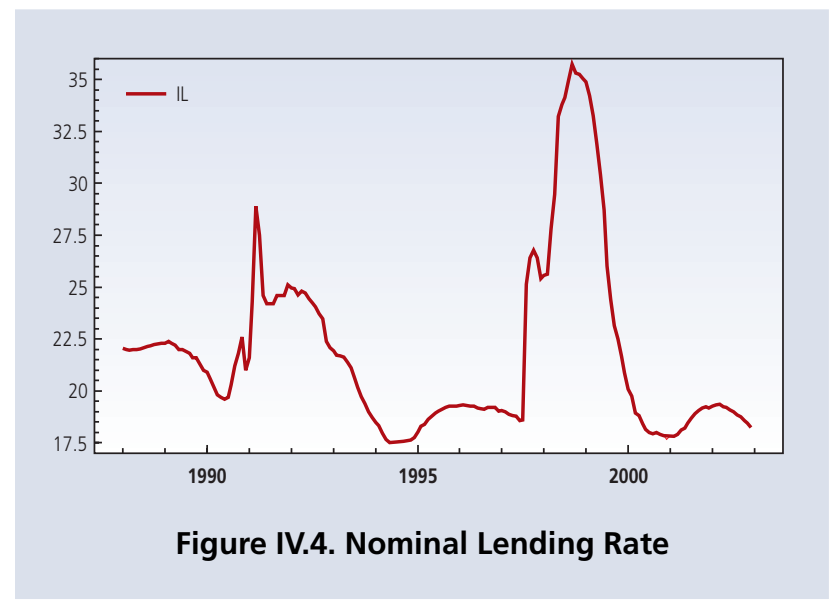

To investigate the relationship between SBI rate and both the commercial bank's rate and lending rate, we develop the simple regression model by ordinary least square (OLS). The result of two models of interest rate is shown on table IV.3 and IV.4.

\begin{tabular}{l|c|c|c|}
\multicolumn{3}{c}{ Table IV.3 } \\
\multicolumn{1}{|c|}{ OLS Result of The First Model of Interest Rate } \\
\hline \multicolumn{1}{|c|}{ Variable } & Coefficient & t-Statistic & t-Probability \\
C & -3.467 & -3.197 & 0.002 \\
SBI Rate & 1.228 & 22.822 & 0.000 \\
\hline$R^{2}=0.745$ & & & \\
\hline
\end{tabular}

\begin{tabular}{l|c|c|c|}
\multicolumn{3}{c}{ Table IV.4 } \\
\multicolumn{4}{c|}{ OLS Result of The Second Model of Interest Rate } \\
\hline \multicolumn{1}{|c|}{ Variable } & Coefficient & t-Statistic & t-Probability \\
\hline C & 15.605 & 46.349 & 0.000 \\
SBI Rate & 0.359 & 21.462 & 0.000 \\
\hline$R^{2}=0.721$ & & & \\
\hline
\end{tabular}

Table IV. 3 reports that the SBI rate and commercial bank's rate has positive relationship, in which the equation is:

$$
i_{b}=-3.467+1.228 * i_{S B I}+\varepsilon
$$


The t-probability of variable ISBI (SBI rate) is 0.00 that means we can accept the alternative hypothesis that variable ISBI is significantly relating to commercial bank's rate. Meanwhile, Rsquared is 0.75 that means variable ISBI can explain $75 \%$ of the interest rate variable and the coefficient of it is 1.228 means that increasing $1 \%$ of ISBI can increase the commercial bank's rate in financial market by $1.228 \%$. It proves that SBI rate as market guidance has strong effect to commercial bank's rate.

From table IV.4, we got the positive link between SBI rate and lending rate, in which the equation is:

$$
i_{l}=-15.6+0.359 * i_{S B I}+\varepsilon
$$

Similarly, we found that t-probability of variable ISBI (SBI interest rate) is 0.00 that means we accept the alternative hypothesis that variable ISBI related to nominal lending rate. R-squared is 0.72 that means variable ISBI can explain $72 \%$ of the lending rate variable. On the other hand, we found that the coefficient of ISBI is 0.359 smaller comparing with first model of interest rate. It means that raising $1 \%$ of ISBI can raise the lending rate in financial market only $0.359 \%$.

This situation can be explained by data of credit on banking sectors that is still low, since the banks are still reluctant to place the funds on the real sectors. Therefore, the effect of SBI rate to lending rate is relatively low. Banks prefer to invest on the low risk instrument, for example buying SBI from Bank Indonesia.

We do not interpret the intercept term in this model, since it has no particular physical meaning. To investigate the causality between SBI rate and both the commercial bank's rate and lending rate, we do Granger Causality test with the result shown on table IV.5.

\begin{tabular}{|c|c|c|}
\hline \multicolumn{3}{|c|}{$\begin{array}{c}\text { Table IV.5 } \\
\text { The Result of Granger Causality Test }\end{array}$} \\
\hline Null Hypothesis & F-Statistic & Probability \\
\hline IB does not Granger Cause ISBI & 12.2226 & 1.1E-05 \\
\hline ISBI does not Granger Cause IB & 5.39669 & 0.00533 \\
\hline IL does not Granger Cause ISBI & 3.42055 & 0.03492 \\
\hline ISBI does not Granger Cause IL & 9.23452 & 0.00015 \\
\hline
\end{tabular}

Since the t-probability below $1 \%$, we can reject both the null hypotheses the commercial bank's rate does not Granger cause SBI rate and SBI rate does not Granger cause the commercial 
bank's rate. It means the Granger causality runs on two ways. SBI rate can cause the commercial bank's rate and vice versa.

Meanwhile, we can not reject the null hypotheses that the lending rate does not Granger cause SBI rate, because t-probability above $1 \%$. On the other hand, we can reject the null hypothesis that SBI rate does not Granger causes the lending rate. It means the Granger causality runs on one way from SBI rate to lending rate, not vice versa.

\section{IV.2 The Effect of Interest Rate to both Consumption and Investment}

To find the effect of interest rate to both consumption and investment, we develop models of both consumption and investment. The macroeconomic time series data is usually non stationary at the level and stationer at the first difference. We need to do unit root test for random walk variables, to find both the stationary of each variable and the order of integration for each variable.

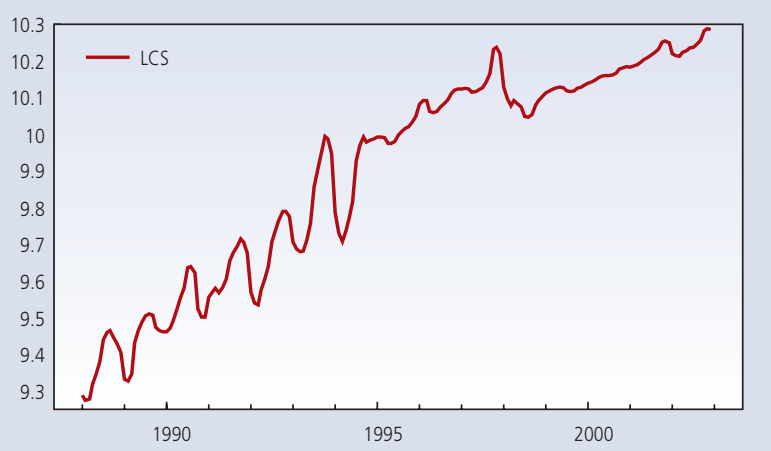

Figure IV.5. Logarithm of Real Consumption

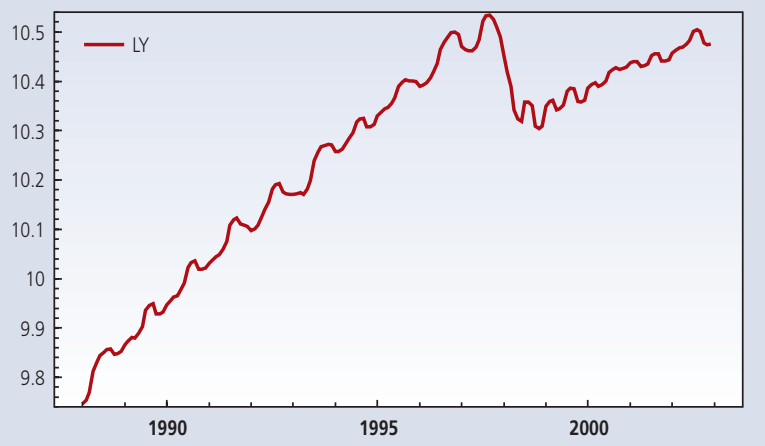

Figure IV.6. Logarithm of Real GDP 


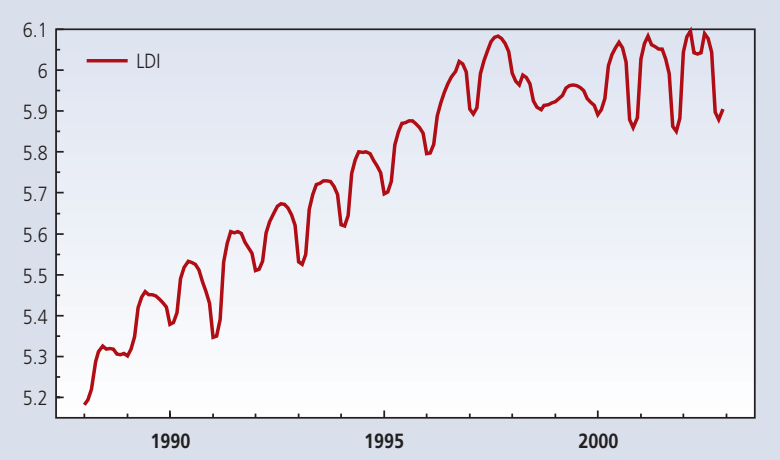

Figure IV.7. Logarithm of Real Disposable Income

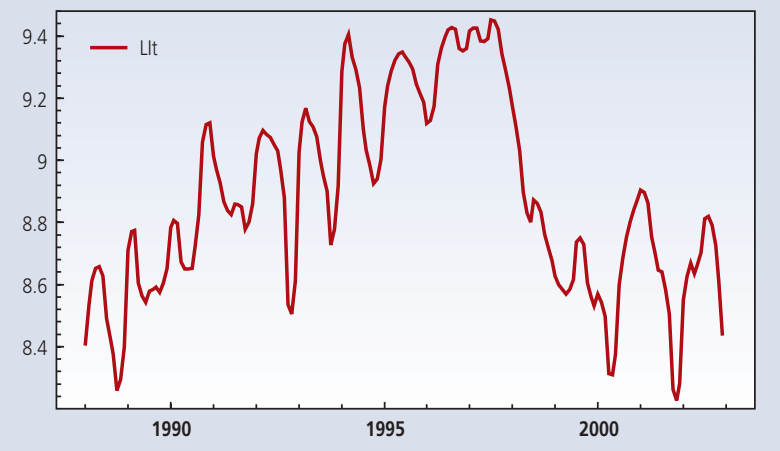

Figure IV.8. Logarithm of Real Investment

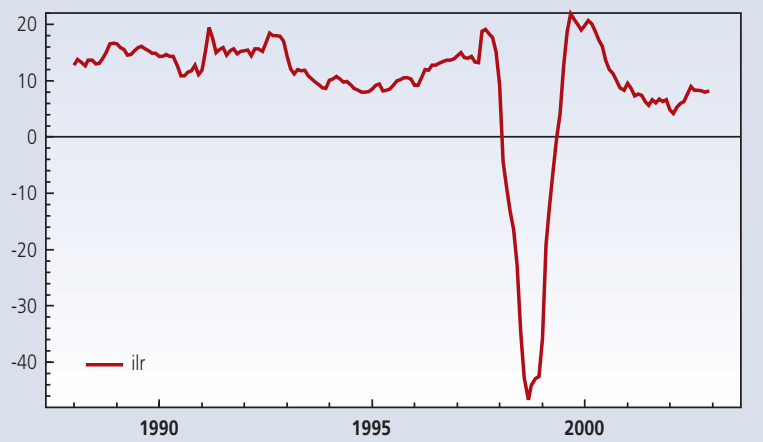

Figure IV.9. Real Lending Rate

Figure IV.5, IV.6, and IV.7 indicates that real consumption, real income and real disposable income have a trend, therefore we do unit root test including constant and trend. Alternatively 
the other variables, such as real investment and real lending rate (figure IV.8 and IV.9) have no trend and no seasonal, therefore we do unit root test including constant only.

We do unit root test on each variable using three lags, because we want to know which lag has no serial correlation with residual in the variable. The null and alternative hypotheses are specified:

$H_{0}:$ Non Stationer

$H_{1}$ : Stationer

\begin{tabular}{|c|c|c|c|c|c|c|}
\hline \multicolumn{7}{|c|}{$\begin{array}{c}\text { Table IV.6 } \\
\text { The Result of Unit Root Test at Level }\end{array}$} \\
\hline No & Variable & Including & $\begin{array}{l}\text { ADF } \\
\text { lag }\end{array}$ & t-ADF & $\begin{array}{c}\text { Critical } \\
\text { Value at } 1 \%\end{array}$ & Result \\
\hline 1 & Real Consumption (LCs) & $\begin{array}{l}\text { Constant \& } \\
\text { Trend }\end{array}$ & 3 & -2.8148 & -4.013 & Not stasioner \\
\hline 2 & Real Investment (LIt) & Constant & 3 & -1.7984 & -3.469 & Not stasioner \\
\hline 3 & Real Income $(Y)$ & $\begin{array}{l}\text { Constant \& } \\
\text { Trend }\end{array}$ & 3 & -1.2867 & -4.013 & Not stasioner \\
\hline 4 & Disposable Income (LDI) & $\begin{array}{l}\text { Constant \& } \\
\text { Trend }\end{array}$ & 3 & -2.4010 & -4.013 & Not stasioner \\
\hline 5 & Real Lending Rate (ilr) & Constant & 0 & -1.4835 & -3.469 & Not stasioner \\
\hline
\end{tabular}

We can summary that at level I(0) all variables and continuously test all variables at first difference. All variables at first difference I (1) are tested including constant only.

\begin{tabular}{|c|c|c|c|c|c|c|}
\hline \multicolumn{7}{|c|}{$\begin{array}{c}\text { Table IV.7 } \\
\text { The Result of Unit Root Test at First Difference }\end{array}$} \\
\hline No & Variable & Including & $\begin{array}{l}\text { ADF } \\
\text { lag }\end{array}$ & t-ADF & $\begin{array}{c}\text { Critical } \\
\text { Value at } 1 \%\end{array}$ & Result \\
\hline 1 & Real Consumption (DLCs) & Constant & 2 & -9.4111 & -3.469 & stasioner \\
\hline 2 & Real Investment (DLIt) & Constant & 2 & -10.568 & -3.469 & stasioner \\
\hline 3 & Real Income (DLY) & Constant & 2 & -10.111 & -3.469 & stasioner \\
\hline 4 & Disposable Income (DLDI) & Constant & 2 & -12.036 & -3.469 & Stasioner \\
\hline 5 & Real Lending Rate (Dilr) & Constant & 2 & -4.3260 & -3.469 & Stasioner \\
\hline
\end{tabular}

We can conclude that all data are stationer at first difference I(1), therefore the order of integration of all variables is one. That means all variable can be cointegrated in the long run. 
Therefore, we can continue to develop model for consumption and investment in Indonesia using Johansen's technique.

\section{IV.2.1 Model of Consumption}

We use logarithm of consumption and logarithm of disposable income as endogenous variable with two lags of each variable. Constant is unrestricted variable. The result of cointegrating vector in the long run consumption is shown on table below:

\begin{tabular}{c|c|c|c|c|c|}
\multicolumn{7}{c}{ Table IV.8 } \\
The Cointegration Result \\
$\begin{array}{c}\text { Null } \\
\text { Hypothesis }\end{array}$ & $\begin{array}{c}\text { Alternative } \\
\text { Hypothesis }\end{array}$ & $\lambda_{\max }$ value & $\begin{array}{c}\text { Null } \\
\text { Hypothesis }\end{array}$ & $\begin{array}{c}\text { Alternative } \\
\text { Hypothesis }\end{array}$ & $\lambda_{\text {trace }}$ value \\
$r=0$ & $r=1$ & $29.14^{* *}$ & $r=0$ & $r>0$ & $33.98^{* *}$ \\
$r=1$ & $r=2$ & 4.846 & $r \leq 1$ & $r>1$ & 4.846 \\
\end{tabular}

Table IV. 8 reports that Trace test statistic undertaking the test for number of Eigenvalues that are insignificantly different from 1 . We get the Trace test is 33.98 (t-probability is below $1 \%$ ), we reject the null hypothesis that $r=0$. At rank 1 , the Trace test is 4.846 (t-probability is above $1 \%$ ), we can not reject the null hypothesis that $r \leq 1$.

Meanwhile, the test of maximum Eigenvalues is 29.14 (t-probability below 1\%) meaning we are able to reject the null hypothesis $r=0$. At rank 1, the maximum Eigenvalues is 4.846 (tprobability above $1 \%$ ) that we can not reject the null hypothesis $r=1$. In conclusion, we obtain only one cointegration by Trace test and maximum Eigenvalues test.

When we find that the variable does not respond to the discrepancy from the long run relationship in cointegrated system, meaning that it is weakly exogenous. Therefore, the speed

\begin{tabular}{|c|c|c|c|c|}
\hline \multicolumn{5}{|c|}{$\begin{array}{l}\text { Table IV.9 } \\
\text { The Result of Weak Exogeneity Test }\end{array}$} \\
\hline Variable & Beta & Std Error & Alpha & Std Error \\
\hline LCS & 1.000 & 0.000 & -0.145 & 0.026 \\
\hline LDI & -1.1399 & 0.059 & 0.000 & 0.000 \\
\hline
\end{tabular}

14 Enders, Walter, "Applied Econometric Time Series", 2004 
of adjustment parameter $\alpha_{i}$ should be zero to meet that the variable is weakly exogenous. The weakly exogenous variable does not experience the type of feedback that necessitates the use of VAR ${ }^{14}$. We test the null hypothesis that $\alpha_{i}=0$.

It reports that the $\mathrm{Chi}^{2}=1.0955$ with t-probability 0.295 that is above $5 \%$. We can accept the null hypothesis that $\alpha_{i}=0$. Therefore, we only use vector of $\ln (\mathrm{Cs})$ as the long run equation.

We obtain the long run equation of consumption:

$$
\ln (C s)_{t}=1.1399 * \ln (D I)_{t}+\varepsilon
$$

Based on economic theory, the real disposable income has positive relationship with the real consumption with coefficient is approximately one in the long run. This is consistent with economic theory, yet the coefficient of disposable income is bigger than 1. Theoretically, people will increase their consumption as much as increasing of their real disposable income. Increasing of real income by $1 \%$ will be followed by increasing of demand for money by $1 \%$ too.

Therefore, we create restriction that impose the unit coefficient on the real disposable income variable becomes one. We are testing the null and alternative hypotheses:

$H_{0}: \beta_{1}=1 \quad$ (Coefficient of real income $=1$ )

$H_{1}: \beta_{1} \neq 1 \quad$ (Coefficient of real income $\neq 1$ )

\begin{tabular}{|c|c|c|c|c|}
\hline \multicolumn{5}{|c|}{$\begin{array}{c}\text { Table IV.10 } \\
\text { The Result of Restriction Test }\end{array}$} \\
\hline Variable & Beta & Std Error & Alpha & Std Error \\
\hline LCS & 1.000 & 0.000 & -0.123 & 0.025 \\
\hline LDI & -1.000 & 0.000 & 0.000 & 0.000 \\
\hline
\end{tabular}

The result on table reports that the $\mathrm{Chi}^{2}=5.7924$ with t-probability is 0.0552 (above $1 \%)$, meaning that we accept the null hypothesis that coefficient of income is equal to one. In conclusion, the unit coefficient of income is one. In the long run, increasing real income by $1 \%$ affects increasing consumption by $1 \%$.

Therefore, the long run model of consumption becomes:

$\ln (C s)_{t}=1.00 * \ln (D I)_{t}+\varepsilon$

From the long run equation obtained by using Johansen's technique, we calculate the 
ECM (Error Correction Mechanism) in which will be applied in the dynamic model. The formula is: $\mathrm{ECM} \_\mathrm{Cs}=\mathrm{LCs}-1.00 * \mathrm{LDI}$

Furthermore, we estimate the short run dynamic model by ECM obtained in the long run equation by Johansen's technique. The short equation is:

$$
\begin{aligned}
\Delta \ln (C s)= & 0.632-0.154 * E^{2} C M C S_{t-2}+0.072 * \Delta^{3} \Delta \ln (D I)-0.0006 * \Delta\left(i_{b r}\right)_{t-5}-0.223 \\
& \Delta \ln (C s)_{t-5}+0.0001 * \text { trend }+\varepsilon
\end{aligned}
$$

\begin{tabular}{l|r|r|r|}
\multicolumn{2}{c}{ Table IV.11 } \\
\multicolumn{1}{|c|}{ The Result of Short Run Equation } \\
\multicolumn{1}{|c|}{ Variable } & Std Error & t-value & \\
Constant & 0.117 & 5.413 & t-probability \\
D3dLDI & 0.020 & 3.579 & 0.000 \\
Dibr_5 & 0.0003 & -2.036 & 0.000 \\
DLCS_5 & 0.067 & -3.332 & 0.043 \\
Trend & 0.00004 & 2.479 & 0.001 \\
ecmcs_2 & 0.029 & -5.346 & 0.014 \\
$R^{2}=0.375$, DW $=1.36$ & & & 0.000 \\
\hline
\end{tabular}

The goodness of fit or $R^{2}=0.375$ that means $37.5 \%$ of the total variation in consumption can be explained by the regression model. The $R^{2}$ is low, since we use differenced variables on the regression model. All explanatory variables are significant that t-probability is below $5 \%$.

We sum up the one variable with different lags if it has the similar coefficient number and we create the new variable. In this model, we create one new variable after summing up their lags. The new variable is $\Delta^{3} \Delta \ln (D I)_{t}$.

$$
\Delta^{3} \Delta \ln (D I)_{t}=\Delta \ln (D I)_{t}+\Delta \ln (D I)_{t-1}+\Delta \ln (D I)_{t-2}+\Delta \ln (D I)_{t-3}
$$

We use $\Delta^{3} \Delta \ln (D I)_{t}$ as disposable income variable. We found that $\Delta^{3} \Delta \ln (D I)_{t}$ is significant (t-prob is 0.0005 below $1 \%$ ), meaning that the lags of the disposable income have the same effect in the long run. The slope of $\Delta^{3} \Delta \ln (D I)_{t}$ is 0.072 , meaning the average amount of consumption goes up at the rate of 0.072 . Based on theory, if disposable income goes up, individual more consumes.

The slope of the real interest rate $\Delta\left(i_{b r}\right)_{t-5}$ is -0.0006 that means the average consumption has been decreasing at the rate of -0.0006 . Theory stated that the real consumption in the short run will decrease when real interest rate increase. Individuals will consume less and they 
prefer to increase their saving. Therefore, consumption will be down when real interest rate goes up.

The elasticity of $\Delta \ln (C s)_{t-5}$ is -0.223 , meaning if real consumption five months ago goes up by $1 \%$, the average consumption goes down by about $0.223 \%$. Theoretically, individual's consumption in the past will affect to individual's consumption now. The affect can be positive or negative, yet in this case the effect is negative.

The ECM lag two months $\left(\mathrm{ecm}_{t-2}\right)$ has t-probability 0.00 that is strong significant, meaning the ECM is still persistent in the system for the past three quarter and influence to the other variables. The speed of adjustment is -0.142 , meaning that ECM can remove $14.2 \%$ of disequilibrium in three months.

Moreover, by graphical analysis comparing between actual and fitted of consumption as shown in figure 10, we can see that both lines (blue line for actual and red line for fitted) are very close. That means the regression model is excellent fit.

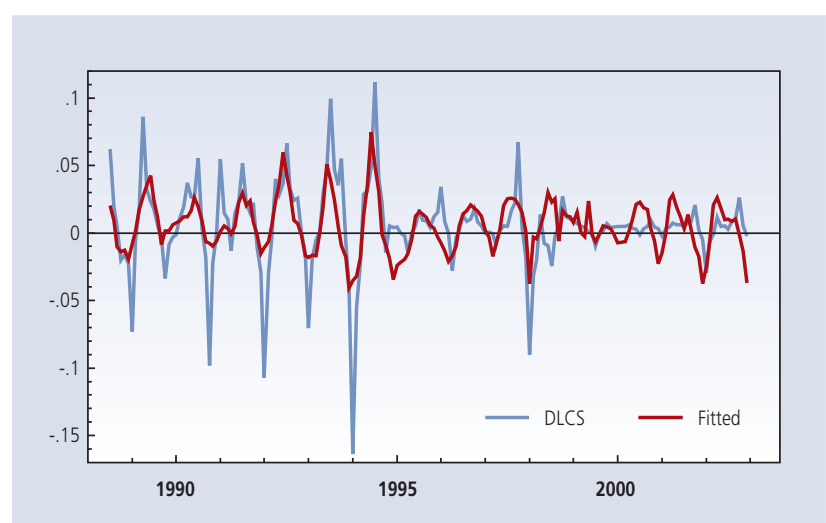

Figure IV.10. Actual and Fitted of Consumption Model

However, we still want to find whether the model has structural change in the linkage between the dependent variable DLCS and other explanatory variables. Sometimes, the structural change of time series model may be caused by external forces or policy changes or other causes.

To find the structural break, we do Chow test that needs the knowledge of the specific time of structural break allowing the sample to be split. However, we can operate recursive procedure in the PCGIVE software to investigate the stability of the model estimates. We obtain the initial recursive is 31, meaning the data started on July 1990. The graph results can be seen in the figure IV.11 to IV.14. 


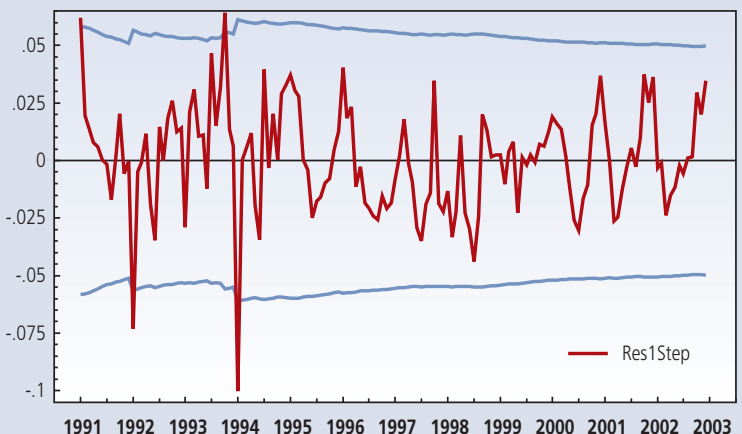

Figure IV.11. One Step Residual

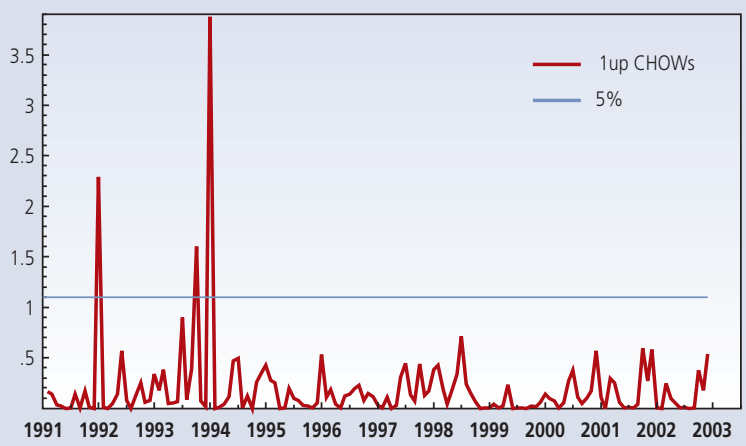

Figure IV.12. One Step Chow Test

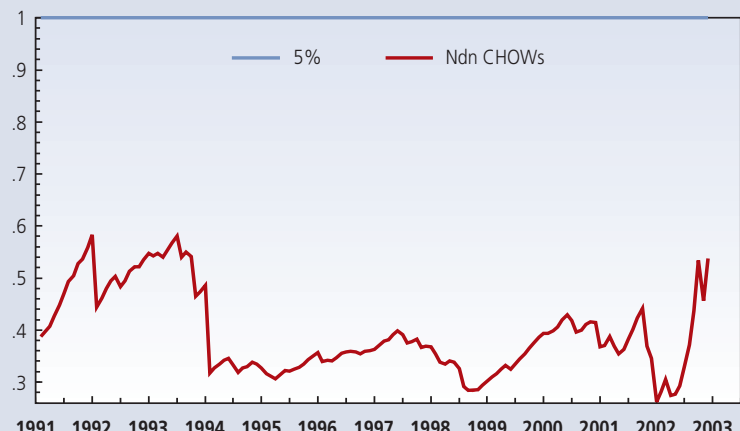

Figure IV.13. Break-point Chow Test

As can be seen on figure IV.11, the residual of the model estimates is still inside upper line and lower line, except on December 1992 and December 1994. Meanwhile, in figure IV.12, except in December 1992, September 1994 and December 1994 the line is below the limit line 


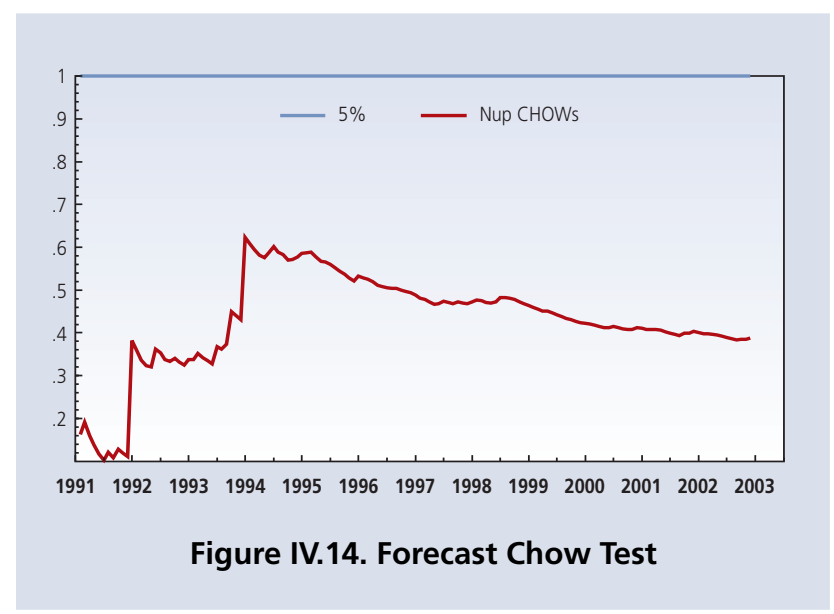

(blue line), meaning the parameter estimate is relatively stable that is supported by figure IV.13 when we do break-point Chow test. The structural break is not happened in any period. Moreover, the forecast of Chow test (figure IV.14) showing the line is below the limit line (blue line). In conclusion, the short run model has no structural break at period sample on July 1990 - December 2002.

\section{IV.2.2 Model of Investment}

To investigate the effect of real lending rate to real investment in the long run, we cointegrate the logarithm of investment, logarithm of real lending rate, and logarithm of real income as endogenous variable with three lags of each variable. Constant is unrestricted variable and trend is restricted variable. The result of cointegrating vector in the long run model of investment is shown on table IV.12.

\begin{tabular}{c|c|c|c|c|c|}
\multicolumn{7}{|c|}{$\begin{array}{c}\text { Table IV.12 } \\
\text { The Cointegration Result } \\
\text { Null } \\
\text { Hypothesis }\end{array}$} & $\begin{array}{c}\text { Alternative } \\
\text { Hypothesis }\end{array}$ & $\lambda_{\max }$ value & $\begin{array}{c}\text { Null } \\
\text { Hypothesis }\end{array}$ & $\begin{array}{c}\text { Alternative } \\
\text { Hypothesis }\end{array}$ & $\lambda_{\text {trace }}$ value \\
$r=0$ & $r=1$ & $74.07^{*}$ & $r=0$ & $r>0$ & $96.87^{*}$ \\
$r=1$ & $r=2$ & 16.81 & $r \leq 1$ & $r>1$ & 22.8 \\
$r=2$ & $r=3$ & 5.992 & $r \leq 2$ & $r>2$ & 5.992 \\
\end{tabular}

We obtain the Trace test statistic that undertakes the test for number of Eigenvalues that are insignificantly different from 1 . At rank 0 , we find the trace test is 96.87 (t-probability is 
below 5\%), we reject the null hypothesis that $r=0$. At rank 1 , the trace test is 22.8 (t-probability is above $5 \%$ ), then we accept the null hypothesis that $r \leq 0$.

Meanwhile, the maximum Eigenvalues test is 74.07 (t-probability below 5\%) meaning we can reject the null hypothesis $r=0$. Then, at rank 1, the maximum Eigenvalues is 16.81 (tprobability above $5 \%$ ) that we can not reject the null hypothesis $r=1$. In conclusion, we obtain only one cointegration by Trace test and maximum Eigenvalues test.

Similarly with long run model of consumption, we do weak exogeneity test. The speed of adjustment parameter $\alpha_{i}$ should be zero to meet that the variable is weakly exogenous. We test the null hypothesis that $\alpha_{1}=0 ; \alpha_{2}=0$.

\begin{tabular}{|c|c|c|c|c|}
\hline \multicolumn{5}{|c|}{$\begin{array}{c}\text { Table IV.13 } \\
\text { The Weak Exogeneity Test }\end{array}$} \\
\hline Variable & Beta & Std Error & Alpha & Std Error \\
\hline Lit & 1.000 & 0.000 & -0.341 & 0.038 \\
\hline$\| r$ & 0.001 & 0.001 & 0.00000 & 0.000 \\
\hline LY & -3.200 & 0.160 & 0.00000 & 0.000 \\
\hline Trend & 0.012 & 0.0007 & - & - \\
\hline
\end{tabular}

It reports that the $\mathrm{Chi}^{2}=5.8615$ with t-probability 0.0534 that is above $1 \%$. We can accept the null hypothesis that $\alpha_{1}=0 ; \alpha_{2}=0$. Therefore, we only apply vector of logarithm of real investment as the long run equation.

We obtain the long run equation:

$\ln (I t)=-0.001 * i_{l r}+3.2 * \ln (Y)-0.012 * \operatorname{Trend}+\varepsilon$

The slope of income is 3.2 matching with ICOR average in Indonesia (3 - 3.5). The slope of the long-term interest rate is -0.001 that means the average investment has been decreasing at the rate of -0.001 . Based on economic theory, increasing interest rate is followed by decreasing investment in long term. People prefer to save than to invest when the interest is high.

The ECM obtained by long run equation is:

ecmi $=$ Lit $-0.0013028 *$ ilr $+3.2001 *$ LY $-0.011983 *$ trend

Meanwhile, parsimonious equation is below:

$$
\begin{aligned}
\Delta \ln (I t)= & 0.689-0.017 * E C_{M C i_{t-1}}+0.449 \Delta \ln (I t)_{t-1}-1.543 \Delta \ln (Y)_{t}-0.242 \\
& \Delta \ln \left(\text { excr }_{t-3}+0.121 * \text { Seasonal }+\varepsilon\right.
\end{aligned}
$$




\begin{tabular}{l|c|c|c|}
\multicolumn{2}{c}{ Table IV.14 } \\
\multicolumn{1}{|c|}{ The Result of Parsimonious Equation } \\
\hline \multicolumn{1}{|c|}{ Variable } & Std Error & t-value & t-probability \\
\hline Constant & 0.382 & 1.802 & 0.073 \\
DLIt_1 & 0.060 & 7.464 & 0.000 \\
DLY & 0.427 & 3.617 & 0.000 \\
Seasonal & 0.020 & 6.043 & 0.000 \\
DLexcr_3 & 0.108 & 2.240 & 0.026 \\
ecmi_1 & 0.009 & -1.846 & 0.066 \\
\hline$R^{2}=0.417$, DW $=1.72$ & & & \\
\hline
\end{tabular}

All explanatory variables are significant with t-probability below $10 \%$. The elasticity of $\Delta \operatorname{Ln}(I t)_{t-1}$ is 0.45 meaning that if real investment previous month goes up by $1 \%$, the average investment goes up by around $0.45 \%$. Previous investment will affect to recent investment. The effect can be positive or negative, but this result shows the positive effect.

The elasticity of $\Delta \operatorname{Ln}(Y)_{t}$ is 1.54 that means increasing real income by $1 \%$ can increase average investment by around $1.54 \%$. Theory stated that people will improve investment if their real income increases.

The elasticity of $\Delta \ln (\text { excr })_{t-3}$ is 0.242 , meaning if real exchange rate three months (one quarter) ago goes down by $1 \%$, the average investment will go up $0.242 \%$. People will invest more when the value of rupiah against US dollar is fall. Holding rupiah is not valuable, therefore they will prefer buy US dollar or invest their money.

The ECM lag one month $\left(\mathrm{ECM}_{\mathrm{t}-1}\right)$ with t-probability 0.067 is significant. It can be interpreted that ECM is still persistent in the system for the past month and influences to other variables.

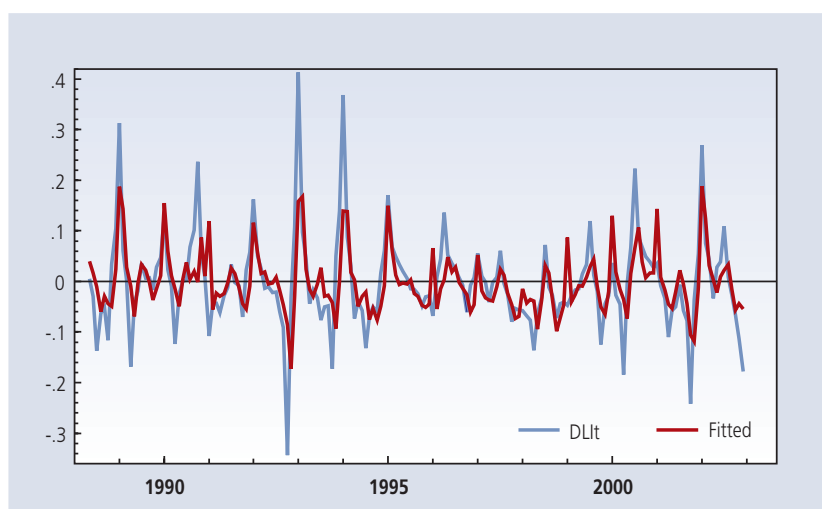

Figure IV.15. Actual and Fitted of Investment Model 
The coefficient of ECM is negative 0.017 implying that $1.7 \%$ of disequilibrium is removed in a month.

The graphical analysis comparing between actual and fitted indicates that regression model is excellent fit, since both lines are very close.

Applying Chow test is to investigate the structural change in the linkage between dependent variable (DLCS) and other explanatory variables. Using recursive procedure in the PCGIVE software, we investigate the stability of the model estimates. The initial recursive is 30 , meaning data started at 1990/6. The graph results can be seen in the figure below.

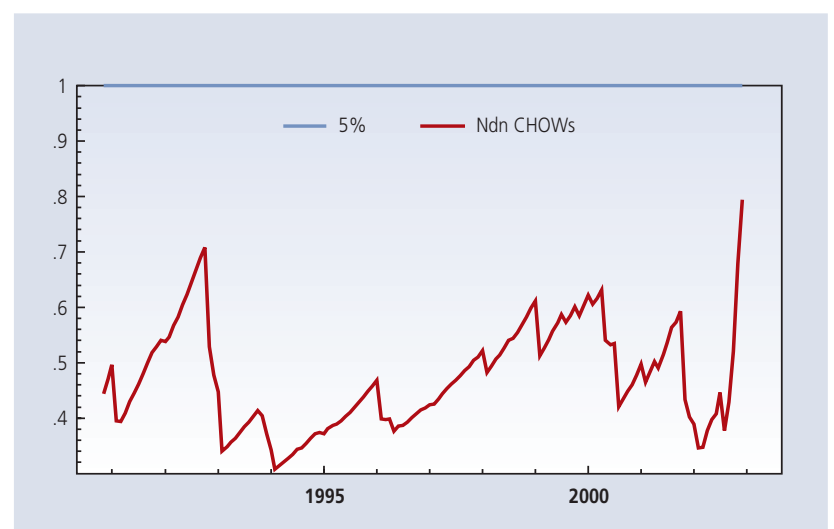

Figure IV.16. Break-point Chow Test

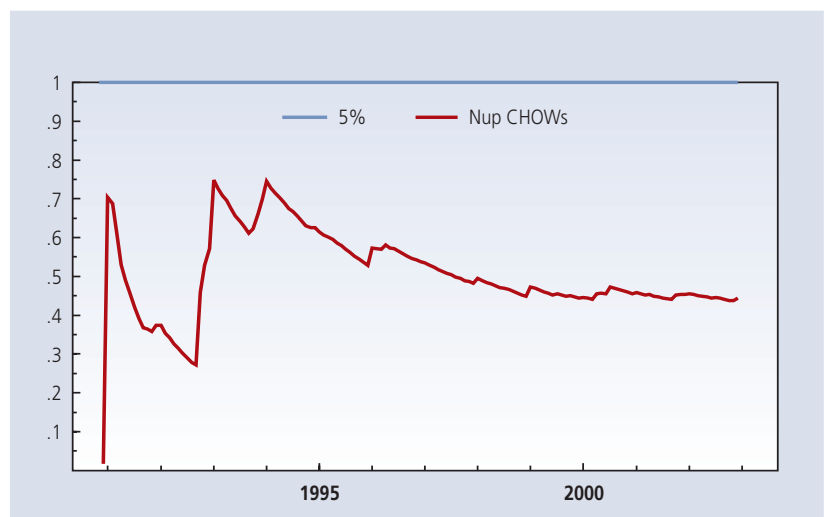

Figure IV.17. Forecast Chow Test 


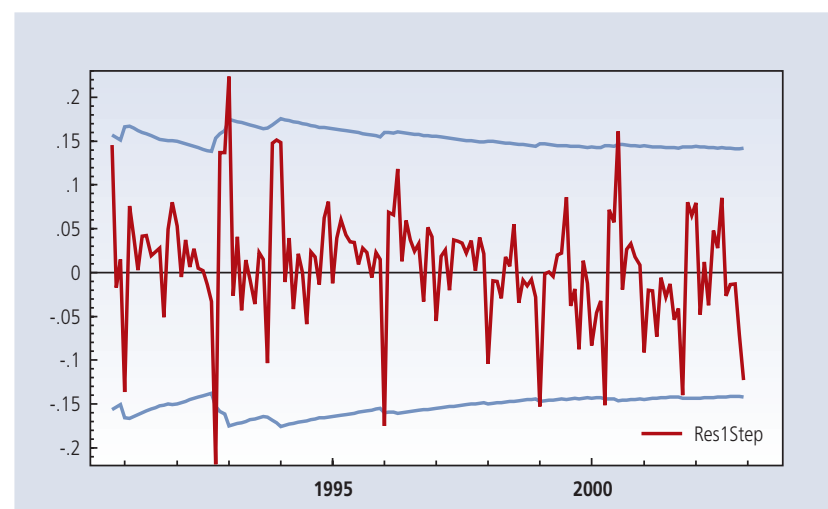

Figure IV.18. One Step Residual

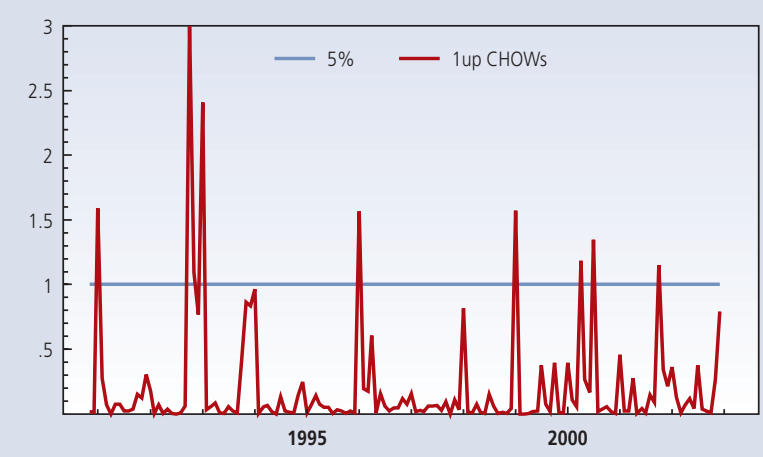

Figure IV.19. One Step Chow Test

Figure IV.16 indicates the residual of model estimates is still in the path, except on October 1994 and December 1994. Meanwhile, in figure IV.17, we attain that the line for in a few period is above the limit (blue line). However, break-point Chow test (figure IV.18) indicates that the structural break is not happened in any period. Moreover, the forecast of Chow test (figure IV.19) shows the line below the limit (blue line). We can conclude that the dynamic model has no structural break at period sample on June 1990 - December 2002.

\section{IV.3 The Effect of both Consumption and Investment to GDP Growth}

Actually, the relation between both consumption and investment and output can be defined as identity equation: $Y=C+I+G+X-M$. However, in this simple regression model, we want to investigate the individually effect of consumption to output and investment to output. We develop the simple model by ordinary least square (OLS). The result of two models of output: 


\begin{tabular}{l|c|c|c|}
\multicolumn{4}{c}{ Table IV.15 } \\
\multicolumn{1}{|c|}{ OLS Result of the First Model of Output } \\
\hline Variable & Coefficient & t-Statistic & t-Probability \\
\hline C & 3.334 & 24.711 & 0.000 \\
Consumption & 0.700 & 51.317 & 0.000 \\
\hline$R^{2}=0.937$ & & & \\
\hline
\end{tabular}

\begin{tabular}{l|c|c|c|}
\multicolumn{4}{c}{ Table IV.16 } \\
\multicolumn{1}{|c|}{ OLS Result of the Second Model of Output } \\
\hline \multicolumn{1}{|c|}{ Variable } & Coefficient & t-Statistic & t-Probability \\
C & 8.090 & 19.433 & 0.000 \\
Investment & 0.244 & 5.203 & 0.000 \\
\hline$R^{2}=0.132$ & & \\
\end{tabular}

The first model: consumption related to output (GDP)

$$
\ln (Y)=3.334+0.70 * \ln (C s)+\varepsilon
$$

The t-probability of variable logarithm of consumption is 0.00 that means it accepts the alternative hypothesis that variable ISBI related to nominal interest rate. R-squared is 0.94 that means variable consumption can explain $94 \%$ of the output variable. The coefficient of consumption is 0.70 means that increasing $1 \%$ of real consumption can increase the output by $0.70 \%$.

The second model: investment related to output (GDP):

$$
\ln (Y)=8.091+0.244 * \ln (I t)+\varepsilon
$$

The t-probability of variable real investment is 0.00 that means the alternative hypothesis that variable investment related to real GDP can be accepted. R-squared is 0.13 that means variable investment can explain only $13 \%$ of the output variable. The coefficient of investment is 0.244 means that increasing $1 \%$ of investment can increase the output by $0.244 \%$. The intercept term in this model is not be interpreted, since it has no particular physical meaning.

Even though the model indicates the strong relationship between both consumption and investment and output, we still need to find the causality among them by Granger Causality test. 


\begin{tabular}{|c|c|c|}
\multicolumn{2}{c}{ Table IV.17 } \\
The Result of Granger Causality Test \\
\hline Null Hypothesis & F-Statistic & Probability \\
\hline LY does not Granger Cause LCS & 3.91735 & 0.00111 \\
LCS does not Granger Cause LY & 2.27406 & 0.03912 \\
LIT does not Granger Cause LY & 1.90925 & 0.08232 \\
LY does not Granger Cause LIT & 4.27500 & 0.00050 \\
\hline
\end{tabular}

Because of the t-probability below $5 \%$, we can reject the null hypotheses the output does not Granger cause consumption and consumption does not Granger cause output. It means the Granger causality runs on two ways. Consumption can cause the real GDP and vice versa.

Meanwhile, we can not reject the null hypothesis that investment does not Granger cause output, because t-probability above $5 \%$. On the other hand, we can reject the null hypothesis that output does not Granger cause the investment. It means the Granger causality runs on one way from output to investment, not otherwise.

\section{SUMMARY AND CONCLUSION}

\section{V.1 Summary}

Regarding to the models of interest rate, it demonstrates the strong relationship between the SBI rate and both commercial bank and lending rate. There can verify that central bank rate can influence directly market interest rate in the financial system. The simple regression models show that $\mathrm{SBI}$ rate goes up by $1 \%$ affecting the commercial bank rate rises by $1.228 \%$ and lending rate rises by $0.359 \%$.

The smaller effect of SBI rate to lending rate comparing to commercial bank rate indicates that banking sectors are still reluctant to provide a credit to real sectors. Intermediate function of banking system is not optimal. After currency crises during 1997-1998, commercial banks tend to place their fund in the financial market with lower risk rather than in real sector, for example SBI auction.

In the meantime, the model of consumption proves that the real interest rate can affect the consumption in the short run. The effect of that is negative implying that growing the real interest rate can reduce the real consumption. If the real interest rate increases by $1 \%$, the real consumption will reduce by $0.0006 \%$. There is consistent with economic theory, even though 
it is only a small effect. Since people prefer to consume than to saving, the rises of real interest rate only decreases a small number of consumption.

On the contrary, the real interest rate has not affected consumption in the long term. Real consumption is only affected by disposable income. The long run model explains that escalating disposable income by $1 \%$ can increase consumption by $1 \%$ based on Keynes consumption theory ${ }^{15}$. People will consume more when their income goes up.

Conversely, the real lending rate has an effect to real investment in the long term, yet it has no effect in the short term. The investment model explains that rising real lending rate by $1 \%$ can lower the real investment by $0.001 \%$ in the long term. Economic theory stated that the correlation between real investment and real lending rate is negative, that means investment goes down if the real lending rate goes up (Mankiw, 2003). Therefore, this investment model can be evidence for investment theory.

The economic growth or GDP growth has robust relation both consumption and investment. Theoretically, mounting both consumption and investment can boost the GDP. The out put models show the consumption effect to output is very high. Increasing consumption by $1 \%$ can affect to increase the real GDP by $0.7 \%$.

The statistically data during sample period 1988-2002 reports that consumption is the biggest contributor to GDP. The Indonesian economic growth is supported by consumption around $20 \%$ annually.

Alternatively, the real investment has a low effect to economic growth. The output model explains that the rising $1 \%$ of investment will increase real GDP only by $0.244 \%$. There is lower than the effect of consumption. This is supported by data that investment is the lowest contributor of GDP. The contribution of investment is below $5 \%$ every year.

\section{V.2 Conclusion}

As mentioned earlier, SBI rate can be as guidance for financial market to determine interest rate. The policy of Bank Indonesia to raise SBI rate will be followed by markets to increase their interest rate, such as commercial bank's rate and lending rate. Even though their effect is not similar, they still follow the trend of SBI rate as central bank's rate.

The interest rate can affect the real sector in which raising interest rate can lower both consumption and investment. The effect of increasing interest rate to consumption is only in

15 Campbell, John Y. and Mankiw, N. Gregory, "The Response of Consumption to Income, European Economic Review 35, 1991, p. 723-767 
the short term. However, it can affect the investment in the long term. For the moment, they can influence the real GDP implying increasing both of them can increase the real GDP. On the other hand, they can reduce the real GDP when they go down.

We can conclude that increasing the SBI rate can shrink the real GDP through financial market. Therefore, central bank can be careful applying interest rate as an instrument policy at inflation targeting framework. They need to consider the effect of changes SBI rate to economic growth, even though it is only small effect.

This research does not specify suggest the level of SBI rate to reach both high economic growth and low inflation rate. It can be developed by simultaneous models to get optimal SBI rate to be applied. However, it can explain the effect of SBI rate to GDP growth gradually through financial system 


\section{BIBLIOGRAPHY}

Alamsyah, H., Joseph, C., Juda, A., Zulverdy, D., "Framework for Implementing Inflation Targeting in Indonesia", Bank Indonesia, 2000

Bank Indonesia, "The Short-term Forecast Model of Indonesian Economy (SOFIE)", Directorate of Economic Research and Monetary Policy, 2001.

Campbell, John Y. and Mankiw, N. Gregory, "The Response of Consumption to Income, European Economic Review 35, 1991, p. 723-767

Dreger, C. and Reimer, H.E., "Consumption and Income in the Euro Area: Empirical Evidence Based on Panel Cointegration Methods", 2000, p.5

Enders, Walter, Applied Econometric Time Series, Wiley, 2004

Iljas, Achjar, "Peranan Bank Indonesia Dalam Pengendalian Inflasi", Bank Indonesia, 1999

Iljas, Achjar, "Inflation Targeting dan Akuntabilitas Bank Sentral", Bank Indonesia, 2001

Johansen, S. and Katarina, J., "Maximum Likelihood Estimation and Inference on Cointegration - with Aplications to The Demand for Money", Oxford Bulletin of Economics and Statistics, 52, 1990, p.169-181

Johansen, S. and Katarina, J., "Identification of The Long-Run and The Short-Run Structure an Application to The ISLM Model", Journal of Econometrics 63, 1994, p.8

Macklem, R. Tiff, "Wealth, Disposable Income and Consumption: Some Evidence for Canada", November 1994, p.4

Mankiw, N. Gregory, Macroeconomics, Fifth Edition, Worth Publishers, 2003

Patterson, Kerry, An Introduction to Applied Econometrics: A Time Series Approach, First Edition, Palgrave, 2000

Taylor, John B., "Summary Remarks at Bank Indonesia", Jakarta, 2000

Taylor, John B., "Discretion versus Policy Rules in Practice," Carnegie-Rochester Conference Series on Public Policy, 39, 1993, p. 195-214.

Walsh, Carl E., "Is New Zealand's Reserve Bank Act of 1989 An Optimal Central Bank Contract?", Journal of Money, Credit and Banking. Vol.27, No.4, 1995

Warjiyo, Perry, "Towards Inflation Targeting: The Case of Indonesia", Bank Indonesia, 2001

Warjiyo, Perry and Agung, Juda, "Transmission Mechanism of Monetary Policy in Indonesia", Bank Indonesia, 2002 
502 Buletin Ekonomi Moneter dan Perbankan, Maret 2006

This page is empty on purpose 